\title{
Implementation Model Assure to Utilize Local Wisdom for Learning Science at Pesantren Sabilil Muttaqien Kediri East Java Indonesia
}

\author{
Budi Setyo Margono \\ State University of Malang, Indonesia \\ budism.education@gmail.com
}

\begin{abstract}
The efective mastery learning of Science needs the learning media which is universal in order to fascilitate student with different need, the learning style and the speed of learning. Beside considering the availabililty and the easeness to obtain, as well as the atractiveness for student. Utilizing bamboo as the learning media functions to demonstrate the proscess of how the soil erosion and sedimentation occur on the waterways which is covered by forest and which is not by comparing the level of turbidity. Completed by modifying short video about various natural disaster related to soil erosion in order to build student's understanding contextually. The learning media is made of bamboo with 2 meters in length helps student to perceive the process of soil erosion and sedimentation in detail. Short video helps student to corelate between student's understanding and the real case.
\end{abstract}

Keywords: learning style, speed of learning, ASSURE Model, local wisdom, erosion

\section{INTRODUCTION}

Fascilitating student to learn in order to get meaningful learning experience, joiful and comfortable learning, is the main concern of the teacher especially at the level of Primary. That's how the inovation of utilizing and modifying the learning media should be one of the effors of the teacher to make it comes true (Sadiman, 2006). Utilizing various learning media which optimize more student's way to learn e.g. by visual, auditory and kinaesthetic, will give more opportunity to achieve the target of learning. Beside learning media, Learning model, student's participation during the learning proces are also important factors since they are influential to take part in establishing learning experience which is meaningful for kids (Asy'ari, 2006).

Learning approach which is universal, appreciate the various learning style individually, fascilitates more student's need either in visual, auditory, or kinaesthetic (DePorter, 2002). It also fascilitates more student's need at the speed of learning, either at low, medium or fast. This learning media is provided by supplement resource, short video, which fascilitates student to corelate the knowledge they establish to the fact at real life, without changing the main learning or target of learning (Smaldino, 2008).

\section{METHODS}

Distributing questionare aims to get respond from teacher and student about how the implementation of the learning media is utilized, as the evaluation to know the strength and the weakness (Arikunto, 2006). Measurement the process of utilizing the learning media refers to Likert scale method whose 4 suitable alternative answers: strongly agree (SA); agree (A); neither $(\mathrm{N})$; disagree (D); and strongly disagree (SD). Each has score: $\mathrm{SA}=1 ; \mathrm{A}=2 ; \mathrm{N}=3 ; \mathrm{D}$ $=4 ; \mathrm{SD}=5$. Observation of the Learning where technology and learning media are utilized according to ASSURE last for 3 days. The learning media is Bamboo, the technology is short video and the participation of the student is the involvement at demonstration, presentation and answering the question. Bamboo as the media to demonstrate the process of soil erosion and short video is the bridge to conect student's understanding to the facts, reality of how the process works naturally. Most of the teaching time in the class, teacher focus on personal approach to each student by guiding, directing or giving help to certain student whose problem in following the learning.

\section{RESULT AND DISCUSSION}

\section{The Efectiveness Level of The Learning}

The measurement of the efectiveness level of the learning is $73 \%$, the everage is 83,16 . It concludes that the learning is able to fascilitate student to learn more efective and eficient. It conveys the message of learning, fullfils all components of learning according to what is needed, and helps to solve the learning problem at subject Science.

\section{Student's Participation}

The preparation is important before the class starts, since the learning needs 2 assistant teachers, they need to know what the activities, the tools, and the medias are. They need to know how it works clearly in order to ensure that the class runs well according to the lesson plan. The place of every group one to another must be in proper distant in order to ease the supervision and not to interupt each other. Each group can free to have discusion among the member to finish task given by teacher.

Teacher provides Syntax at a piece of paper as reminder and guide to manage time in order to finish them on time, and list of questions to evaluate how much the material is absorbed by student. Teacher has to be aware of student's need in order to give help when needed and finish the task ontime since they still have agenda to review the learning together on which teacher gives sharpening and reinforcement toward the objective of the day. That is the important things should occur among teachers to keep the learning on the track.

\section{Heterogen Group}

Student is grouped into 5 , each has heterogen in term of gender and level of academic. Teacher has stated the seating arrangement by which each student 
within group is observable by teacher in front class. Among groups do not interupt one to another, meanwhile among student within a group can communicate one to another when teacher gives question. To stimulate student's participation, teacher provides scoringboard to conduct brainstorming session, by which every student who is able to give respond get poin.

\section{Working within Group}

Each group has a laptop to watch short video provided by teacher, and 3 pieces of papers to write the result of discussion. Teacher explains the activity has to be done by each group step by step before they work together and how each student has to help each other and participate actively to contribute idea or solution within group's discussion to finish the task and get the best result.

\section{Teacher's Role}

During the process of learning, teacher observe them one by one and aware of those who needs help, otherwise just give them opportunity to work cooperatively within group and motivate them by personal approach. Those who needs help teacher should give just clue in order to let them learn to solve it independently.

After discussion session is over, each group's worksheet is submited to teacher and scored and to have sharpening and reinforcement toward what they have just done. Continued by postest to know how much they are able to absorbed the material of learning.

\section{Result of Pretest and Posttest}

Result of pretest and postest shows the student's achievement at the area of cognitive, it is at table below (Table 1). Subject Science is related to the way of how to inquire the nature works sistematically, so that, science is not only about mastering knowledge which consist of fact, concept, pinciple, law and theory but also about the process how student acts as the inquirer. The expectation of the science education is as the media to explore student itself, the nature around and the further development prospect to be implemented at the daily life. The learning process of subject science emphasises at providing direct experience to develope competency in order to be able to explore and understand the nature around scientifically. Science education is directed to the achievement of inquiry and action which helps student to get deeper understanding about the nature around (Depdiknas, 2002).

Table 1

Result of pretest and postest

\begin{tabular}{|c|c|c|c|}
\hline \multirow[b]{2}{*}{ No } & \multirow[b]{2}{*}{ Name } & \multicolumn{2}{|c|}{ Score } \\
\hline & & Pretest & Postest \\
\hline 1 & Afif Yogi Muzaiyana & 50 & 80 \\
\hline 2 & Ahmad Yusnaf Fawwazi & 46 & 88 \\
\hline 3 & Bayu Aji Pamungkas & 56 & 80 \\
\hline 4 & Dea Octavia Rahmadani & 56 & 88 \\
\hline 5 & Elvira Ainun Junaidah & 48 & 80 \\
\hline 6 & Fatma Dianatul Khusna & 56 & 86 \\
\hline 7 & Izza Gibran Maulana Ahmad & 30 & 78 \\
\hline 8 & Lailatul Dyah Puspita & 60 & 92 \\
\hline 9 & M. Rozaqi Ghoniyul Ulum & 30 & 84 \\
\hline 10 & Melinda Tata Putri Nizami & 40 & 82 \\
\hline 11 & Nafisa Rizki Arinandita & 40 & 88 \\
\hline 12 & Nayla Annasywa Putri Wibowo & 30 & 78 \\
\hline 13 & Parisya Aurelio & 30 & 76 \\
\hline 14 & Pradizca Aprilio Nur Fahrezi & 40 & 84 \\
\hline 15 & Rafi Ahmad Nizhamul Hasin & 40 & 84 \\
\hline 16 & Salsabila Alya Nurlaili & 40 & 82 \\
\hline 17 & Selly Isma Damayanti & 50 & 80 \\
\hline 18 & Ulimah Nour Aira & 46 & 88 \\
\hline 19 & Zahara Sabila Alfian & 58 & 84 \\
\hline & Total score & 846 & 1582 \\
\hline & Everage & 44,53 & 83,26 \\
\hline
\end{tabular}

The area of learning which is expected student to get after the learning are: (1) cognitive, student is able to recall, understand, apply and analyse the material is given by teacher, according to Bloom Taxonmy they are categorized at $\mathrm{C} 1-\mathrm{C} 5$, this expectation is determined by comparing pretest and postest; (2) afective, attitude or feeling of the student along the period of time in following process of learning, such as confidence, responsibility, risk-taker, collaboative, independent, caring; and (3) psycomotoric, action of the student along the process of learning as participation in teamwork (Depdiknas, 2002).

\section{CONCLUSION}

Modifying learning media bamboo in the implementation of learning follows the steps of ASSURE model and provided with short video as the bridge to help student to corelate their knowledge to the example at the reality. It fascilitates student's need whose various learning style and speed of learning, especially at the part of the material which is abstract or needs contextual example, so that it prevents from verbalism.

The learning process forces student to participate actively through small teamwork which stimulate to build comunication skill among the members. The teamwork's task are to demonstrate 
process of soil erosion and to observe a case study of natural soil erosion through short video. The following action is teacher gives them opportunity to discuss the problem with teacher's guide.

Reflection at the end of class are sharpenning and reinforcement of findings which is inquired by student within group, beside knowing how much the material is absorbed by student. The efectiveness level of learning media is measured by comparing the result of pretest and postest. It is $84.21 \%$ and the everage is 83.26.

\section{REFERENCES}

[1] Arikunto S. 2006. Prosedur Penelitian Suatu Pendekatan Praktik. Jakarta: PT Rineka Cipta.

[2] Arsyad, A. 2014. Media Pembelajaran. Jakarta: Rajagrafindo Persada.

[3] Asy'ari, M. 2006. Penerapan Pendekatan SainsTeknologi-Masyarakat dalam Pembelajaran Sains di Sekolah Dasar. Yogyakarta: Universitas Sanata Dharma Yogyakarta.

[4] Depdiknas. 2002. Pengembangan Pelaksanaan BroadBased Education, High-Based Education, dan Life Skills di SMU. Jakarta: Depdiknas.

[5] DePorter, B. 1999. Quantum Learning. Jakarta: Kaifa.

[6] Suprayekti. 2003. Interaksi Belajar Mengajar. Jakarta: Depdiknas.

[7] Mayer, R. E. 2001. Multimedia Pembelajaran Pinsipprinsip dan Aplikatif. Yogyakarta: Pustaka Belajar.

[8] Sadiman, A., Rahardjo, R., Haryono, A., \& Rahardjito. 2006. Media Pendidikan: Pengertian, Pengembangan, dan Pemanfaatan. Jakarta: Rajagrafindo Persada.

[9] Smaldino, S. E., Lowther, D. L., \& Russell, J. D. 2008 Istructional Teknology \& Media for Learning: Teknologi Pembelajaran dan Media untuk Belajar. Jakarta: Kencana. 